\title{
TEACHER TRAINING FOR THE PREVENTION, REPORTING AND ADDRESSING OF VIOLENCE AGAINST CHILDREN
}

\author{
Elisabetta Biffi, \& Daniela Bianchi \\ "Riccardo Massa" Department of Human Sciences for Education, University of Milano-Bicocca (Italy)
}

\begin{abstract}
Each year an estimated one billion children (one out of two children worldwide) suffer some form of physical, sexual or psychological violence or neglect (Hillis, Mercy, Amobi, \& Kress, 2016). Being a victim of violence in childhood has lifelong impacts on education, health, and well-being. Exposure to violence can lead to poor academic performance due to cognitive, emotional, and social problems (WHO, 2019). The right of the child to freedom from all forms of violence is affirmed by the United Nations Committee on the Rights of the Child, in its General Comment No. 13 (UNCRC, 2011). Moreover, the Sustainable Development Goals contain a clear call to eliminate violence against children, most explicitly in Target 16.2 (UN, 2015).

Many efforts have been made globally to achieve these goals. Schools have been identified as one of the crucial contexts for conducting violence prevention efforts. They offer an important space where children, teachers and educators can learn and adopt pro-social behaviors that can contribute to preventing violence (WHO, et al., 2016). Teachers can play a key role, helping to build a "violence-free world" (UNESCO, WHO, UNICEF, End Violence Against Children, 2020), both by promoting positive relationships and by identifying signs of violence early. In fact, while international strategies provide a necessary framework for the promotion and protection of children's rights, it is the people who can make a difference in the prevention and detection of violence against children (Biffi, 2018).

Based on these premises, the paper will focus on how teacher training can help prevent, report and address violence against children. Teachers are often not trained on this: some of them know the contents, but have doubts about how to deal with certain situations. Teachers should learn what to do with students who have gone through a traumatic experience because children choose someone who can see and recognize them (Miller, 1979, En. transl. 1995; Miller, 1980, En. transl. 1983). To be able to really recognize the child, a training course with teachers is necessary, to raise awareness and help them see the signals that children send (The Alliance for Child Protection in Humanitarian Action, End Violence Against Children, UNICEF, WHO, 2020). This paper, through literature and presentation of a training course with teachers in Italy, will offer a pedagogical reflection on teacher training in the prevention, reporting and addressing of violence against children, in order to start building a common shared strategy.
\end{abstract}

Keywords: Teacher training, violence against children, prevention, rights of the child, Italy.

\section{Violence against children: Prevention starts at school}

In accordance with the definition provided by the World Health Organization, violence is «The intentional use of physical force or power, threatened or actual, against oneself, another person, or against a group or community, that either results in or has a high likelihood of resulting in injury, death, psychological harm, maldevelopment or deprivation» (Krug, Mercy, Dahlberg, \& Zwi, 2002, p. 5).

The right of the child to freedom from all forms of violence is affirmed by the United Nations Committee on the Rights of the Child, in its General Comment No. 13 (UNCRC, 2011). Moreover, the Sustainable Development Goals contain a clear call to eliminate violence against children, most explicitly in Target 16.2 (UN, 2015). Although children's rights are formally recognized, each year an estimated one billion children (one out of two children worldwide) suffer some form of physical, sexual or psychological violence or neglect (Hillis, Mercy, Amobi, \& Kress, 2016).

Being a victim of violence in childhood has lifelong impacts on education, health, and well-being. Exposure to violence can lead to poor academic performance due to cognitive, emotional, and social problems (WHO, 2019). It has been reported that children who have experienced violence display 
difficulties at school, in terms of deficits or delays in their skills development and knowledge acquisition (McKee, \& Dillenburger, 2009).

Schools have been identified as one of the crucial contexts for conducting violence prevention efforts. They offer an important space where children, teachers and educators can learn and adopt pro-social behaviours that can contribute to preventing violence (WHO, 2016). Teachers and educators are in a position to contribute to the early identification of maltreatment and family violence in general, although it is a complex task (Walsh, et al., 2008). At the same time, teachers and educators have a professional relationship with families that allows them to support parents and promote a positive parental attitude. Indeed, several studies have underlined the role of schools (Baginsky, 2003; 2007) and demonstrated that, if child protection is to be effective, it is crucial for teachers and educators «to be clear and confident about their own pastoral role with regard to sensitive issues of child protection, especially when collaborating in multidisciplinary child protection work» (McKee, \& Dillenburger, 2009, p. 3). Teachers can play a key role, helping to build a "violence-free world" (UNESCO, WHO, UNICEF, End Violence Against Children, 2020), both by promoting positive relationships and by identifying signs of violence early. In fact, while international strategies provide a necessary framework for the promotion and protection of children's rights, it is the people who can make a difference in the prevention and detection of violence against children (Biffi, 2018).

\section{The teacher-child relationship}

In the relationship with the child there is an issue of ambiguity, with respect to what is legitimate to act on him/her. Children choose someone who can see and recognize them (Miller, 1980, En. transl. 1983). It is therefore necessary to learn to be aware of how one is in relationship with a child who is living or has gone through a traumatic experience. In order to really recognize the child, a training course with teachers is necessary, to raise awareness and help them see the signals that children send (The Alliance for Child Protection in Humanitarian Action, End Violence Against Children, UNICEF, WHO, 2020).

Teachers should learn to stay in the classroom with children who have experienced a traumatic experience on their skin, because, among the many consequences, it is an aspect that has an incredible impact on learning. In order to achieve this goal, it becomes important to work on themselves and understand which resources to activate. It is necessary to know how to stay in relationships with their students, in particular with children with difficult life stories (Bertolini, Caronia, 1993). Learn to stay inside the uncomfortable stories, to stay inside the fatigue. Even when faced with a child with a tough story, the difficulty lies with the adult because it is he/she who perceives it as such. It is therefore necessary to take charge of the relationship for what it is, with one's own difficulties and with those of the child, which must be recognized and understood. It is not possible to work immediately on the child's behavior, which should instead be seen as a sign of discomfort. Stopping at the symptom risks being counterproductive because it could prevent teachers from understanding what lies behind that particular behavior. So before acting on the student and his/her family it is necessary to work on themselves. To do this, a relationship of trust is needed, not only with the individual child, but with the whole community of the school, the family, the territory. Only in this way will it be possible to open a new horizon for the child and focus on his/her well-being. If teachers are able to make their students feel good at school, children can be given the opportunity to know that school can be a positive place, a place where they can feel good. This should be the primary goal of teachers and of the entire school community.

\section{A training course for teachers in Italy for the prevention of violence against children}

With these premises, the contribution aims to explore teacher training on the prevention of violence against children through the presentation of a course for teachers in Italy. The course started from a specific need of the territory and the teachers to receive training on the prevention and reporting of violence against children, following some episodes that occurred with their students. The training course was promoted by a Municipality of a suburban area of North Italy and the University of Milano-Bicocca and involved some schools in the area, from kindergarten to high school.

The purpose of the course was to facilitate the identification and treatment of children in situations of prejudice and severe discomfort with preventive and guidance effectiveness. Furthermore, through the course teachers have been made more aware of the dimensions on which they most need to strengthen themselves both as individuals and as services. The training course has also contributed to the knowledge of the child protection services in the area, promoting better networking between schools and the Municipality. 
At the end of the training, the path will continue in schools, where the trained teachers will become reference points for the entire school, with a view to sustainability.

Due to the COVID-19 restrictions in Italy, the course had to be held remotely, but took place in laboratory mode encouraging activities in small groups. During the first meeting the expectations and needs of the teachers involved were explored. From the dialogue with them it emerged that they do not receive specific training on the prevention of violence against children and even if they know the contents, they say they do not feel confident about how to deal with certain difficult situations. The teacher's doubts are mainly summarized in the inability to see a need and, once identified, in not knowing how to manage it. It was therefore necessary to build sharing strategies to know how to deal with situations of violence against children, which teachers could witness or see their signals, also promoting prevention thanks to early and shared actions. During the training, the teachers were able to learn to recognize a situation, to deal with it and to activate the resources around them, with a view to continuous collaboration with the social workers of the Municipality.

Starting from the needs identified by the teachers, the course was developed according to different objectives: to help teachers "see" and "hear" the children in their school, to orient themselves with respect to their own way of being at school and to network with territorial protection services. In fact, it is important to prepare the personal ground for understanding how to be predisposed to feel the risk of violence with the children they work with. Furthermore, at school there is often the risk that some modalities that are used in the daily educational relationship may become echoes for those who have experienced violence. Those who live in a difficult story have a high sensitivity with respect to some modes of relating. Although there are differences between children's age groups, some words (Biffi, 2020) or gestures, such as that of the teacher to approach the child's body, are never neutral. With children who are victims of violence this gesture becomes even more meaningful. The educational relationship passes through the body and the teacher must be even more aware of it when the child experiences suffering. Another fundamental aspect is networking with local services: it is necessary to work as a team to have a complete vision of the child's life and to be able to deal with any uncomfortable situations in the best way for the child and his/her family. The training course therefore wanted to give teachers and the protection services of the Municipality a space to reflect on their experiences and professional skills, in order to understand what resources are already there and what skills must be refined to better live the relationship with students and families and to deal with any difficult situations.

To achieve these objectives the course was based on experts' presentations, discussion of critical cases, plenary discussion sessions, narrative writing, use of images and videos. The intention was to create an informal space for the teachers involved, based on T-group method (Lewin, 1947) and Sensitive Group approach (Rogers, 1970), in order to make them reflect on their stereotypes and prejudices, on their experiences with children at school and on how to deal with hypothetical future situations. This is because there is no objective dimension when it comes to the relationship between teachers and students. Teachers cannot rely on the objectivity of the experts or on their own objectivity. In educational relationships there is always a subjectivity, which makes the role of teachers more strategic in preventing violence against children, but at the same time makes their task even more complex. It was therefore essential not to provide teachers with a pre-filled vademecum, but to build together with them a common strategy to make them more aware of the necessary steps and of the people they could ask for help. Collaboration with child protection services was fundamental, providing teachers with useful information on the reporting process in the event of childhood violence, and was also useful in terms of building a future work network. Both talked and tried to understand each other's needs, in order to build a common and shared working strategy.

Through group work, some concerns were clarified and resources that already exist within the school were discovered. This confirms that, unfortunately, there is still a lack of dialogue within the school today. Teachers expressed the desire and the need to repeat this training course cyclically to give the opportunity also to new teachers to participate and to refresh their memory regularly. Very often it is assumed that the teacher knows all the services in the territory and all the people who work within them. The risk is to pass information only to those responsible and not to involve the entire school community in the process of preventing violence against children.

The training course made it possible to bring out three aspects in particular: it is important to recognize and understand how to use the resources that are already present within the school; increase the level of sensitivity in general in order to have a "trained look" with which it will be less difficult to see certain situations; a child who is unwell does not learn, or if she/he learns it uses it as a mask to hide a discomfort. The collaboration between teachers and social workers then highlighted the need for greater dialogue and mutual trust and the importance of finding an effective communication channel, a common language for better teamwork. Both expressed the need to have a constant and regular moment of dialogue between the various services. Being able to create routines helps a lot of different services to work together, there is a need for regularity. A network intervention works if the nodes are solid and interconnected with each other, otherwise families risk falling into the holes in the net. 


\section{Conclusion}

Reflecting on violence against children is fundamental because in the teacher-child relationship patterns of the parent/adult-child relationship are repeated. It is therefore essential to consider these situations with a broader view. Teachers and educators should also help each other to reflect on some practices and styles that take place within the school and that have an impact on children. In fact, it is not always possible to read how the words and gestures of teachers can have an effect on the personal stories of their students. For this reason teachers should observe both the children and themselves in the relationship with them, continually questioning themselves. By building reflections on their actions they will be able to connect with children because what they do at school is related to what happens in the whole life of the child.

The first factor of prevention is the knowledge of the child, knowing how to recognize him (Miller, 1979, En. transl. 1995), so that any violence against the child can be recognized early. The key tools that teachers and educators should equip themselves are observation and listening, which also depend on how spaces and times are managed at school. It is therefore important to create a school culture capable of putting children at the center. This listening and observing attitude is always useful, not only in cases of violence. If the relationship is missing, learning also fails. Teachers and educators should be able to listen empathically to children, so that they will feel free to ask for their help if necessary. Signs of maltreatment and violence are often little or no visible and can only be identified by paying close attention to the child's behavior. Furthermore, teachers are required to have knowledge of the official procedures as, once the risk factors are identified, it is necessary to know exactly which steps to follow (Biffi, 2018).

To do this, it is necessary to learn not to work alone and to have spaces and times for sharing with colleagues within the school, with the experts who supervise them, with the families and with the territory by creating a strong alliances. At the same time, it is also important to work on the whole class because if a student has a discomfort the whole class will suffer.

The goal is to guarantee children the right to protection against violence, focusing on the best interests of the child (UN General Assembly, 1959; 1989). Childhood is a common good and for this reason it must be protected.

\section{References}

Baginsky, M. (2003). Newly qualified teachers and child protection. Child Abuse Review, 12, 119-127. Baginsky, M. (2007). Schools, social services and safeguarding children. Leicester: NSPCC.

Bertolini P., Caronia L. (1993). Ragazzi difficili. Pedagogia interpretativa e linee di intervento, Firenze: La Nuova Italia.

Biffi, E. (2018). Training Teachers to Prevent Violence Against Children: The First Line Against Family Violence. In K. Trimmer, R. Dixon, \& Y. Stewart Findlay (Eds.), The Palgrave Handbook of Education Law for Schools (pp. 519-532). PALGRAVE MACMILLAN.

Biffi, E. (2020). When educational words become violent. The risk of hate speech within the educational relationship, MeTis, 9(2), pp. 101-117.

Hillis, S., Mercy, J., Amobi, A., \& Kress, H. (2016). Global Prevalence of Past-Year Violence against Children: A Systematic Review and Minimum Estimates. Pediatrics, 137, e20154079. https://doi.org/10.1542/peds.2015-4079

Krug E.G., Mercy J.A., Dahlberg L.L., \& Zwi A.B. (2002) The World Report on Violence and Health. Switzerland: World Health Organization. Retrieved 18.02.2021 from: https://apps.who.int/iris/bitstream/handle/10665/42495/9241545615_eng.pdf;jsessionid=2F9F6BB 450AF91E897BD80F5AC6B9B20?sequence=1

Lewin K (1947) Frontiers in group dynamics: Concept, method and reality in social science; equilibrium and social change. Human Relations, 1(1), pp. 5-41.

McKee, B.E., \& Dillenburger, K. (2012). Effectiveness in child protection training for pre-service early childhood educators. International Journal of Educational Research, 53, 348-359.

Miller A. (1979): The Drama of Being a Child: The Search for the True Self, En. Transl. London: Virago, 1995.

Miller A. (1980): For Your Own Good: Hidden Cruelty in Child-Rearing and the Roots of Violence, En. Transl. New York: Farrar Straus Giroux, 1983.

Rogers, C. (1970). Encounter Groups, New York: Harper and Row; London: Penguin. 
The Alliance for Child Protection in Humanitarian Action, End Violence Against Children, UNICEF, WHO (2020). COVID-19: Protecting Children from Violence, Abuse and Neglect in the Home. Retrieved 18.02.2021

from: https://www.alliancecpha.org/en/system/tdf/library/attachments/technical_note_covid19_and_its_implicationhs_for_protecting_children_from_violence_in_the_home_v1_0.pdf?file $=1$ \&type $=$ node $\&$ id $=38088$

UNESCO, WHO, UNICEF, End Violence Against Children (2020). Global status report on preventing violence against children. Retrieved 18.02.2021 from: https://www.who.int/publications/i/item/9789240004191

United Nations (2015): Transforming our World: the 2030 Agenda for Sustainable Development. Retrieved

from: https://sustainabledevelopment.un.org/post2015/transformingourworld/publication

UN Committee on the Rights of the Child (2011). General comment No. 13 - The Right of the Child to Freedom from all Forms of Violence.

UN General Assembly (1959). Resolution adopted by the General Assembly. 1386 (XIV). Declaration of the Rights of the Child. A/RES/14/1386.

UN General Assembly (1989). Convention on the Rights of the Child. 20 November 1989, United Nations, Treaty Series, vol. 1577.

Walsh, et al. (2008). Case, teachers and school characteristics influencing teachers' detection and reporting of child physical abuse and neglect: Results from an Australian survey. Child Abuse \& Neglect, 32(10), 983-993.

World Health Organization, et al. (2016). INSPIRE: Seven strategies for ending violence against children. Luxembourg: World Health Organization. Retrieved 18.02.2021 from: file://C:/Users/user/Downloads/9789241565356-eng.pdf

World Health Organization (2019). School-based violence prevention. A practical handbook. Switzerland: World Health Organization. Retrieved 18.02.2021 from: https://apps.who.int/iris/bitstream/handle/10665/324930/9789241515542eng.pdf? sequence $=1 \&$ isAllowed $=y$ 